Teach to live or live to teach: A case study on the educational beliefs of displaced teachers in Taiwan

Su, Yu-Nan $\measuredangle$

National Chengchi University, Taiwan, ROC (334001@yahoo.com.tw)

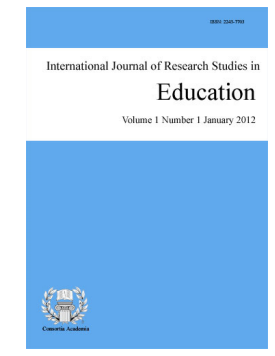

Accepted: 24 June 2011

ISSN: $2243-7703$ Online ISSN: 2243-7711

OPEN ACCESS

\title{
Abstract
}

Current changes in the Taiwan's Teacher Education Law has brought forth new and diverse outlook on Taiwan's teacher education. The law aims at breaking the traditional conservative approach on teacher education; a provision which allow students of non-education degree (as oppose to graduates of normal colleges) to pursue teaching credentials, hence providing a more diverse choice in teacher selection. However, the over expansion of schools who provide such kind of teaching credentials, has resulted in the over saturation of the market with surplus workforce, thus leading to extreme competition of the job market and the appearance of the concept of teachers without regular jobs, vagabond teachers, or just simply displaced teachers. This phenomenon is being herald as the resulting problem of the Taiwan's Teacher Education Law, however, few studies has been conducted on such relevant issues. Therefore, in order to further understand the issue, this case study shall focus on the so-called displaced teachers' educational beliefs and the factors that may affect the teachers' choice of career. Individual semi-structured interviews were conducted on twelve (12) displaced teachers, to understand the impact of educational beliefs on their attitude in facing the intense career competition. Result shows that there is a direct correlation between the teachers' current career choice and their initial educational beliefs. Findings shall serve as a point of reference for contemporary visions on future teacher education policy.

Keywords: teacher's knowledge; teacher's belief; teacher's characteristics; educational beliefs; displaced teachers 


\section{Teach to live or live to teach: A case study on the educational beliefs of displaced teachers in Taiwan}

\section{Introduction}

The Teacher Education Law an amended implemented in February 7, 1994, did not only brought forth a new and multivariate look regarding teacher education, but it also resulted in a number of problems, such as the surplus of persons qualified to teach or simply put the overflow of teachers. In reality, after the implementation of the Teacher Education Law, the government-supported students in normal universities, all the other students trained for teachers have to pass the teacher licensure examination before they could take up their teaching career. Too many academic credits are setup for competition between college students without considering the trend of declining birth rates, causing too many teachers-to-be to attend the tests year after year. According to statistics in the past three years (2006-2008), the acceptance rates of elementary teachers in Taiwan were respectively $0.34 \%$, $1.1 \%$ and $0.7 \%$. Such excessively low acceptance rates have lead to the phenomenon of teachers without regular jobs or displaced teachers.

In Taiwan, since the acceptance rate of teachers becomes lower and lower and fewer and fewer students attend normal universities, transition is extremely urgent. No existing elimination systems for unqualified teachers and as well as the trend of declining birth rates, will make the problem of teachers without regular jobs increasingly serious. In this case, the new teachers without regular jobs in each year have become a force that cannot be ignored. After the annual tests for teacher jobs, reports of cheating in the tests for teacher jobs and public opinions pleading on behalf of teachers without regular jobs occur everywhere, which shows that teachers without regular jobs have become a force that cannot be ignored as a product of education reform. Besides, the present economic depression and decreasing employment intensifies the worry whether teachers without regular jobs, in and of themselves, are a reactionary force of education reform. Such a situation leads to the issues: What kind of mentality of injustice do the teachers without regular jobs have? How to keep a balance between teaching and learning in the teaching work of teachers without regular jobs? What are the educational beliefs of teachers without regular jobs in face of intense completion? What drive them to persist on their career path?

Currently, there are nearly 100,000 qualified teachers who don't have a permanent position. The so-called displaced teachers in this paper refers to students who has education credit required by Education Act of Teachers' Qualification and tried at least once on the teacher selection examination but fails the joint examination (for national schools) or fails to obtained a formal teacher's qualification from the private school. Displaced teacher; this phenomenon, is unique to the excessively opened teacher training market in Taiwan. The noun itself refers to the unsettling situation of student teachers receiving full training for teachers and practicing but failing to secure a work as teachers. Within this context, this paper shall aim at distinguishing the difference between the teachers' attitude of continuing the teacher selection examination or the abandonment of examination and choosing another career.

What kind of teachers, results in what kind of student. Teachers control the whole teaching process, and have the responsibilities of cultivating and teaching. The academic performances and behaviors of students being cultivated are greatly influenced by teachers. Therefore, teachers can be said to be the key to the success or failure of education (Garmon, 2004; Wu, 1998). Studies have showed that teaching beliefs is closely related to teaching practice. In actual teaching activities, the feedback to teachers from academic performances of students, reactions of parents and the interaction with the school administration systems can also modify the teachers' teaching beliefs, and such that the process of continuous interaction proceeds in a cycle (Wang, 2000). Beliefs about teaching are also fostered through literature, and folklore (Lasley, 1980). The study by Tang (1993) is based on the hypothesis that "the conduct of teachers are guided by their beliefs", and there is an interactive relationship between teachers and their conducts, therefore, there is a certain kind of relevance between the two 
elements.

Theory and research about teachers' beliefs also emphasizes that the teachers' beliefs and their teaching behavior can't be separated (Cabello \& Burstein, 1995; Kennedy, 2006; Tabachinick, 1985; Tatto, 1998). In addition, many studies have showed that teachers may have different teaching beliefs due to different backgrounds, and may make a lot of different decisions, which affect their teaching modes (Levin, 2008; Tang, 1993; Yan, 1996; Zhuang, 1993). As educational beliefs have a guiding role to teachers, researchers, from the perspective of educational beliefs, may need to further study into the relevant factors affecting these educational beliefs of individuals, in order to find out the implicit meanings of beliefs. In short, this case study shall aim to adopt a qualitative method paradigm and take the displaced teachers as the object of study, to explore into and analyze in depth the educational belief and the factors that may affect their educational belief.

\subsection{Research objectives}

Based on the above aim, this case study takes displaced teachers s as the object of study to deeply explore into its educational belief in the teaching work and the relevant beliefs that may affect the educational belief. Research objectives are as follows:

1. To understand the education belief of the displaced teachers.

2. To understand the factors related to the educational belief of displaced teachers.

3. To understand the difference between teachers already giving up the selection examination and those still unsettled displaced teachers.

\section{Literature reviews}

\subsection{Definitions}

This section simply sorts out the definitions of education belief given by various scholars, and tries to define the scope and categories of education beliefs, with a purpose to grasp of the nature of education beliefs in depth through the analysis of the literature review in order for more accurate and objective research. Based on the study by local and foreign scholars, the definitions of education beliefs are listed as follows.

Foreign scholars:

$>$ Clark (1988) defines education beliefs as predetermined concepts and implied theories, and explores teachers' attribution of the learning outcomes of students through personal experiences, beliefs, values, stereotypes and prejudices.

$>\quad$ O' Loughin (1989) states that teacher' teaching beliefs refer to the knowledge and perceptions of teachers in their own subjects, the connotation of which includes the nature of knowledge, relevant teaching, child development theories and historical and social foundation of education methods, and many others.

$>\quad$ Pajares (1992) mentioned that a teaching-oriented description of education beliefs, defining teaching orientation as beliefs of "teachers to students", "course of study", "the roles of schools in society", "the roles of the teachers themselves", "Curriculum and Teaching" and other related issues. These tendencies and beliefs also include the questioning of the goals of school education, teachers' responsibilities for not achieving the objectives and students' abilities to achieve the goals.

$>\quad$ Pearson (1989) said that teaching is a kind of intentional activity. When engaged in teaching, teachers must have the intention or goal to make students acquire access to certain things, and the intentions of 
teachers in teaching come from their experiences and what they know or believe.

$>$ Calderhead (1981) proposed that teaching beliefs are divided into five (5) areas: 1. Beliefs about learners and learning; 2. Beliefs about teaching; 3. Beliefs about subjects; 4. Beliefs about how to teach; and 5. Beliefs about individuals and teaching roles.

Local scholars:

$>\quad$ Ling (1990) mentioned that education beliefs are the meanings given by teachers in terms of five areas of beliefs, i.e., "knowledge and learning", "teacher's roles", "the diversity of students", "the roles of communities", and the "schools and society".

$>\quad$ Huang (1994) states that an evaluation and judgment system of the values of the factors related to teaching of teachers in their professional areas. The formation of this system integrates part of rational knowledge, the knowledge in the past, and prejudiced subjective likes and dislikes, including the views, opinions and ideas of teachers as to all the factors related to teaching, such as teachers' views about students, the characteristics of students, teacher-student relationships, the duties of teachers, and others.

$>\quad$ Tang (1993) mentioned that teaching belief refers to the concepts held and believed by teachers in the teaching process as to all the relevant factors.

$>$ Lan (1995) proposed that teaching belief refers to teachers' perceptions of the knowledge of the subjects, including the perceptions of the nature of knowledge, teaching, child development theories, the history of education and social foundation.

$>\quad$ Zhou (1999) states that the views held by teachers and related to teaching processes, a psychological tendency of conviction, total approval and acceptance, related to previous experiences, changeable but not easily changeable, and a guideline to support teaching activities.

Based on the above definitions, the author defines education beliefs as: all the beliefs of education-related factors in the teaching process held by teachers, related to previous experiences and influences the intentions desired to achieve in teaching.

\subsection{The factors that affect the teachers' educational beliefs}

It can be seen from the above definitions of education beliefs that education beliefs are affected by the previous experiences, values and emotional likes and dislikes of individual teachers. As to the factors that affect the education beliefs, the author, based on the collation of the literature review, describes as follows:

\subsubsection{Personal factors}

\section{A. Personality traits}

Personality traits are affected by families, genes, and even the teachers in the past. But regardless of the relationship between these factors, personal traits integrate and manifest these factors in behaviors. The personality traits of teachers will definitely affect the teaching beliefs of teachers (Ling, 1990, Huang, 1994).

\section{B. Genders}

Under the long-term influence by society, males and females play different roles and behave differently in addition to the physical aspect. In the study of the education beliefs of Chinese elementary teachers, Ling (1990) found out that female teachers have more aggressive education beliefs about achievements of students than male teachers; Tang (1993), Lan (1995), and Yan (1996) assume that the genders of teachers do not necessarily have 
different impacts on education beliefs.

\subsubsection{Environmental factors}

\section{A. Home environment}

Home environment not only shapes the personality traits of an individual teacher, but also exerts great influence on a teacher in his/her teaching. A chaotic environment will make it difficult to concentrate on teaching.

\section{B. Studying experience in school days}

A teacher in school days easily becomes the target of copying in future teaching. Children like to imitate those important persons in their minds. The so-called important persons refer to those having biggest impacts on their life (Bandura \& Walters, 1963).

\section{Personal educational background}

Tang (1993), Lan (1995), and Yan (1996) believe that the colleges and departments which the students graduated from have less impact on them than other factors.

\section{Intern experiences}

The accumulation of education beliefs probably starts in childhood and students receive the education beliefs delivered by colleges and universities in the process of acquiring education credits. But in the intern period, education beliefs may change greatly by the real situations in the intern period.

\subsubsection{Duty-related factors}

\section{A. School factors}

Lin (1987) found out in research that compared with teachers in schools in remote areas, teachers in urban areas have significant higher expectations in self selection of specialized fields. In addition, the factors, such as the scale of a school, school culture, interaction between colleagues, and many others, directly or indirectly impact the education beliefs of teachers.

\section{B. The characteristics of students}

Mayer (1985) pointed out that the characteristics of students is an important factor that directly influences the education beliefs of teachers, and forms a link of teaching environment to force teachers to shape teaching beliefs in a particular way.

\section{Parents}

Mayer (1985) believe that due to the interference of parents, teachers have to amend the original teaching beliefs. At the wave of open education, due to the increasing parental participation and education selection, parents' expectation of teachers also directly or indirectly affect their education beliefs.

\section{Teaching length}

Brousseau, Book, and Byers (1988) pointed out in a study about teachers-to-be and teachers that the teaching experiences of teachers are an important factor affecting the education beliefs of teachers. Chinese scholar Ling (1990) also reached a similar discovery that teacher with a service length of shorter than fifteen years have more open-oriented education beliefs than teachers with a service length of longer than fifteen years. 


\section{E. Teaching progress}

The teaching process is limited by teaching progress, and will change the original beliefs of teachers due to the limit of times.

Based on the analysis of the above factors, education beliefs are cultivated with the influence by the above-mentioned factors. Therefore in interviews, it is necessary to find out the factors that may affect education beliefs apparently manifested, and to discover the education beliefs which may not be detected even by the objects of study.

\section{Research methodology}

In recent years, the application of the Teacher Education Law has brought forth a new and multivariate look of teacher education in Taiwan, originally aimed at breaking the original conservative approach of teacher education to convert the situation of graduates from normal universities dominating the job market for teachers, and to provide more accessible jobs to more people willing to be devoted in educational career. But the unlimited number due to improper control results in the employment difficulties of over saturation, thus leading to extreme competition of the job market and the appearance of the concept teachers without regular jobs or Displaced Teachers. This problem has become an important consideration as the product of Taiwan's education reform. As few studies have been conducted, it is an attractive focus as to the education beliefs of the teachers without regular jobs to face the current situation in Taiwan. Accordingly, this study is a case study with teachers without regular jobs as the object of study, adopting the methods of interviews and participant observation to understand the impact of the education beliefs on its attitude to face the intense career competition.

Education beliefs are unique and very personal part of a teacher. And in order for a specific and deep understanding of the education belief of a teacher, the qualitative study method, compared with the quantitative study method, is more capable of showing the unique and specific information of an individual teacher. Huang (1991, pp. 36-37) pointed out that qualitative researchers are interested in a particular type of subjects, not just in an objective view of the literature, but mulling over the accidental incidents or opportunities in the past or present life experiences... on the other hand, if not based on the personal reflection, caring and curiosity of the researchers, qualitative studies of problems are likely to become empty or dull. To sum up, the paper tries to induce qualitative studies for study-depth interviews conducted with a view to really understand the education beliefs and the factors that may affect the education beliefs.

\subsection{Case selections}

After graduation, the researcher keeps in touch with the objects of study. In reflections of the research subject in classes, the researcher first thought of the special identity of the objects of study. After consultation with and consent of the objects of study, the research subject was preliminarily determined, and was finally determined as the present subject after many times of speculations and modifications.

In the study, the research takes up all the jobs, such as data collection, analysis, observation, interviews, and linguistic presentation, and many others. The tasks of independent literature reading, data analysis and summarization of study were carried out as expected. During the interviews, the researcher initially started with non-structured questions with a purpose to create closer relationships. But the other steps of the interviews were conducted with semi-structured questions to seek for the general ideas of the questions in accordance with the outline of interview, and then further detailed inquiries were carried out, with a purpose to understand the factors that may affect the education beliefs of the objects of study.

The study adopts the methods of purposive sampling and snowball sampling. Starting from the familiar teacher without regular job, the researcher asked him to introduce other teachers without regular jobs for 
A study on the educational beliefs of displaced teachers in Taiwan

interviews. A total of twelve (12) participants of study were interviewed. After enough data were collected, the researcher classified the education beliefs of the objects and the factors that might affect their education beliefs.

\subsection{Research paradigm}

There are a variety of ways of data collection in a qualitative study. This is because in the qualitative study anything serving the purpose of the study can be used as the data of the study. Almost any method can be a method to collection information in qualitative study. Chen (2004) assumes that the most important questions in data collection include: How to acquire from the objects of study the information that can demonstrate what they think and what they do? How to understand their actions and the significance structures from their perspective? As this study adopts the method of qualitative research to explore into the education beliefs of individual teachers, the data collection of adopts the two ways, i.e., interview and observation.

\subsection{Data processing and analysis}

Documentation and analysis followed Stenhouse's (1985) categorization style of case data. The researcher summarized key themes, reflections, and insights in a field log after each session. Afterwards, field logs and focus group recording were reviewed to generate a list of key themes. Weekly two hour sessions were scheduled to discuss emerging themes. The aim of the weekly sessions was to identify trends and patterns that reappeared within the individual interviews. A case record was established for each individual interview and focus group interview. Data were kept intact as a way to illuminate meaning and insights in relation to case by case processes and to gleam themes and sub-categories across all cases under study. This approach limited the possibility of losing important themes of each case (Stenhouse, 1985). Primary themes were determined after all data were transcribed as case records. Topics and emerging themes were recorded and a master list was generated. A reexamination of case records was completed followed by formation of one case study.

\section{Results and discussions}

The study takes twelve (12) displaced teachers as the study object. The interview continued from December 2008 till May 2009, the material was fully prepared in the six months. In the research, three groups including persistent examinee for teachers, returned examinee once giving up the examination, and examinee once participating in the examination but giving up was chosen to draw comparison concerning teaching belief in order to find the teaching belief persisting in Taiwan with a low examination admission rate. As to the selected four objects are continuing the preparation for teacher selection examination at present, their codes are from A to $\mathrm{D}$; and codes for the 4 once giving up the selection examination and changing career but returning to sit the teacher selection examination are from $\mathrm{E}$ to $\mathrm{H}$; and codes for the 4 already giving up teacher selection examination are from I to L. The collected material obtained in the depth interview is vast and complex. This chapter will discuss and analyze the relevant research material one by one according to the research questions.

\subsection{What's the teaching belief of displaced teacher?}

In face of so narrow a threshold of low admission rate for teacher selection examination, why someone continues striving for the examination? Why someone give up? And why someone returned to prepare the examination after giving up? What's the reason for the difference of their belief? First, it can be found that teaching belief of the four (4) continuing to prepare the examination (A to D) and the four (4) changing career once but returning to sit the examination for teacher selection (E to $\mathrm{H}$ ) comes from inner purposefulness, and their expectation of the teaching job is self-realization and satisfaction of achievement.

I once changed career many times but I felt I was earning money instead of living. Later, I recalled the sense of accomplishment from teaching others when I acted as the group leader and trained the staff. (F-2009/01/29) 
Parents are teachers and they exert great influence on me. I especially like the environment of school since young. I once worked in the trading company for a short time in my college years. Later, I gave up the job of teaching and turned to business, however, long gaze at computer in the office compartment everyday made one lifeless... I like the feeling of getting along with children, I enjoy teaching them, and I prefer the feeling of growing up together with them. (G2009/01/15)

As to me, I was often in touch with children in the university association, and the feeling is good after the contact, I gained something, later, I studied the teaching course provided by the school. (A-2009/01/12)

For my parents are both teachers, thus, I chose the department of education naturally. I think teachers really have great influence, I mean, students resemble teachers. So it will be tired when first engage in teaching. But it will gradually get its shape as I wish. Then it is unnecessary to pay close attention to them, and I get my sense of accomplishment. (B-2009/01/21)

As to the eight (8) persistent displaced teachers, teaching is ideal job. In the interview, it can be found that they generally like the environment of school. And they feel the sense of accomplishment got from teaching is no-comparable compared with other career, they prefer to face people to thing when it comes to job. Of them, four (4) returned to teaching after changing career, they like teaching more after comparison. As to this expectation of teaching, it is education for education's sake, that is to say, teaching activity is end-in-itself, in-built, non-tool, nor non-materialistic, and it is not activity with motivation and objective beyond education.

As to the four (4) giving up the teacher selection examination (I to L), their expectation of teaching is not in-built, instead, it is the satisfaction caused by the good salary of teaching and its stable payment. In college, when choose department of education, their mind-set is non-exclusive or they have other consideration. When finding the admission rate is excessively low, they decisively gave up desired teaching job selection after sitting teacher selection examination in the first year.

In fact, I don't have the mind to be a teacher, instead, I intended to study in business school, but my family opposed. Then I had a sister working as a teacher, so I thought it wasn't a bad idea to be teacher. Thus, I was not excluding teaching itself. Coincidently, I passed the teacher selection examination and I decided to study for future teaching career. (J-2008/12/16)

My first consideration was to go to Taipei when filling in my aspiration, and department of education was filled in accidently. Teachers left me a very deep authoritative impression on me before. But the great demonstration made teachers lost the right to punish physically, it was somewhat... I personally agree with give physical punishment, and I feel I lost the authority of being a teacher when cannot give physical punishment. (I-2009/01/17)

All my family members are teachers since I was young, and teaching is the career respected by us. When someone among the relatives or friends happens to be teachers, they would think the girl has good condition. (L-2009/01/21)

At first, methinks teaching, the job, was stable, and my family strongly recommended it. However, God knows the sea change over these four years. (K-2009/01/21)

As to the four (4) displaced teacher already gave up, their original reason for choosing department of education included studying in Taipei University, expectation from the family, reputation of teachers, and the stability of teaching. And their reasons didn't cover their own experience and love towards teaching. Teaching was not the job to fulfill the expectation of self-realization. Instead, teaching is only career meeting their demand of working environment and reputation. The reason for the 4's selection to be teachers are not in-built, but instrumental and materialistic, and teaching is activity with motivation and objective beyond education itself, 
what they pursue is the external value of teaching.

\subsection{Relevant factors influencing the teaching belief of displaced teachers}

Combining with the above statement of displaced teachers' teaching belief, the result of the study, and the analysis and summation of the researcher, this passage is discussing the relevant factors influencing the belief of displaced teachers. The researcher discuss the factors influencing the belief of displaced teachers through three sections including personal characteristic, environmental factor, and factor relevant to position-holding, and many others.

\subsubsection{Personal factors}

Concerning personal factor, gender makes no great difference in the result. Individual personal characteristic is important factor influencing education belief. One indulging in the comfort of school environment and having concentrated teaching attitude tends to continue to prepare for teacher selection examination:

I feel teachers of the same academic year are friendly to each other, and they support each other. And even troublesome parents of students can be dealt with. I think there will always be strange things happening everyday in the school, and every day is interesting. (C-2009/01/08)

For I was conscientious in everything, I won't randomly gave my teaching for I just was a substitute teacher. I wasn't that kind of people. Though I was very tired, I still put all my heart into teaching, and there would be no extra time for reading. (B-2009/01/21)

I like the living environment of national primary school very much. Though teaching was not as simple as what I had imagined. But all the time after class is mine. Unlike many other jobs, working overtime is usually needed without enough time to eat well. (E-2009/01/12)

One generally holding no high opinion of school environment and teacher interactive mode tends to give up sitting teacher selection examination. Do you know doing practice and working as a substitute teacher rid people of their original enthusiasm engaging in teaching, for dark side of the school is usually showed when doing practice and working as a substitute teacher. (L-2009/01/21)

The school is factually a very narrow environment. I didn't like the get-along of teachers of the same school year. I felt all were talking about living trivial without any interest... and many teacher would participate in the fighting game of badminton, those didn't participate would go home directly and it was very bored. Should I come here only for playing badminton for a lifetime? (I-2009/01/17)

According to the observation of one holding no high opinion of school environment and teacher interactive mode, it is that the 4 of them have no in-built enthusiasm towards educational work and they only made their choices according to external factors. Once there were difficulties to be resolved in the school, it would become worse, and they tended to view educational work with negative and critical perspective. On the contrary, though the 8 continuing to prepare for teacher selection examination found it no easy task to teach, they showed no fewer enthusiasms. The main reason is that they love educational work itself and view it as the place to strive for self-realization.

\subsubsection{Environmental factors}

And environmental factors can be divided into three aspects including environmental factor of the family, studying experience in school-days, and practice experience for discussion. And there is no special difference found in individual educational background. 
A. Environmental factor of the family

Environmental factor of the family is mainly the influence on individual teaching belief exerted to by the parents, and there is no big difference among the three groups: as to my father, I think he is responsible person and the same character of mine is also influenced by him. Besides, he enjoys reading. I also enjoy reading. Maybe it is for the reason. (E-2009/01/12)

The personality of my mother is very serious. She is a very conscientious in everything. Besides, she is a workaholic, and I am somewhat like this. I am conscientious and I have the self requirement to some degree. (J-2009/01/16)

The reason for my dream for being a teacher since young was because both my parents were teachers. I liked to get along with children and liked the feeling of teaching... I also had no interest in money and business. (H-2008/12/23)

My parents are teachers, my father is the principal, and many parents of the students all have confidence in them. I also learn a lot from them. (K-2009/01/02)

\section{B. Learning experience of school-days}

Learning experience of school-days has great influence. Only one of them will continue to prepare for teacher selection examination mainly for his interest. Class operation manner is self-explored without special influence from others. (B-2009/01/21)

The rest 11 are under the influence of teachers in national primary and middle school, and their views of education and class operating manner is influenced.

... Later, I was transferred to this school, and I had great liking for the classing operating style, I found it very funny. While teachers of my former school always gave a beating when mistakes occurred, their class was always serious, and you won't feel worse. But here, apple adding method is adopted, if you participate in each group of contest, apples will be added, so I find it very exciting. And this is also the manner I like. Then I like this teacher very much for I like his teaching method. Factually I was then a very conscientious child. However, maybe my former teachers only taught according to the book. No one cared about judging what you were like or whether you like this teaching method or not. And no one paid attention to you. I had no good achievement in class. I was not held high by my teachers. But when I came to this school, I found this teaching method was what I liked. I always consider this method good. Thus, I adapt well. Later, when I was asked to teach as the substitute teacher, I usually adopted the grouping contest method to make for the interest in the class. (D-2009/01/24)

In the statement by A, E, K, L, what is given the most attention in teaching is to let children feel happy, and this is also deeply influenced by teachers of national primary school. Other teacher also held high moral and handling affairs teaching $(\mathrm{C})$, order $(\mathrm{F}, \mathrm{J})$, class management and communication with students $(\mathrm{H})$, stimulation of the imagination and deduction ability (J), and what students experience in the school (G). After confirming these, all have something to do with the influence received from teachers of national primary and middle school. Here, it is proved again that the influence of learning experience in childhood will not only increase the interest of students towards education activity but also make them imitate to teach after becoming teachers.

I hope my students can grasp what I teach. It is the most basic to understand the content of the text and then to arouse their motivation. (Question: is it just like the influence exerted by teaching belief of national primary school?) Yes. My teacher in primary school once said, learning was like building high-rise tower, if the foundation was not laid solidly, the upper floor won't be built successfully. It is maybe the same belief. Thus, I say to the children that it is 
A study on the educational beliefs of displaced teachers in Taiwan

dangerous if you fail to understand what I am teaching now for further learning cannot be continued without understanding. (I-2009/01/17)

\title{
C. Practicing experience
}

It was found in the interview that for the current admission rate of teacher selection examination is too low, once the practicing teacher was told to prepare for the examination by the practicing guiding teacher or changing career, most of them showed forgiveness and wouldn't spend more time in practicing. Still, there were some found enough time to study, tending to pass the teacher selection examination. (E) However, there were some practicing guiding teachers unwilling to engage in guiding, instead, they left the formal work to practicing teachers. Thus, negative mood would be easily showed to the school and teaching belief by the practicing teacher.

\begin{abstract}
In fact, I was not happy from the beginning to the end, for I feel in that environment that... that I was not fully respected, then he (the practicing guiding teacher) would leave all work to me, never sharing any teaching technique with me nor paying attention to how I did my teaching. He usually used the class hour to handle his own affairs, or just slept inside the classroom, rather nasty... then, when students put forward questions, he would simply leave the parents of the students to me. When I was not good at be teaching, the situation had been like this. He didn't give me any support. Thus, I was not under his influence... and that environment made me uncomfortable. (L-2009/01/21)
\end{abstract}

It can be judged from the interview result that, practicing experience exerted little influence to the belief of displaced teachers. The current admission rate of teacher selection rate is so low and many practicing guiding teachers all know the importance of examinations, thus, many displaced teachers won't engage in teaching when practicing, instead, they will study in library, let alone teaching technique and the study of practicing guiding teachers, that fails to live up to the name of practicing system. Only one displaced teacher (L) met the irresponsible guiding teacher, who left all work to him. Situation like this and the heavy pressure of examination will influence the wish of practicing teachers to engage in education later. Combine these two loose and tight results, it can be found that, the crux of practicing system lies not alone in individual difference of practicing guiding teacher. Admission rate of the examination is too low, and one acquiring the qualification must first participate in the practicing, and this is the real answer to why practicing system exists in name only in Taiwan.

\subsubsection{Factors relevant to position-holding}

Factors relevant to position-holding includes five (5) like school factor, characteristic of students, parents of students, length of teaching service and teaching progress. School factors are mainly rural and urban difference, school scale, and school culture, and many others. In this research, for the over-plus of Taiwan teachers, nearly all displaced teachers still preparing for the teacher selection examination or just passing the examination work as the substitute teachers in rural areas. Besides, for one failing to pass the teacher selection examination can only work as the substitute teacher, the school demands little of them. In the research, no significant impact was found on teaching belief by different schools, and this can be reflected in teaching progress. No pressure was found in teaching progress of substitute teachers, thus, there was no impact on education belief. Concerning student's characteristic and parents of students, all the twelve (12) displaced teachers view parents of students and students as positive boosting power, and no significant difference were felt. In the length of teaching service, displaced teachers are not formal teachers or even "novice teacher". Thus, they all stay in the stage of study. In face of the examination, all of the twelve (12) feel they are under great pressure. The pressure is not from teaching but the uncertainty of the examination year by year.

\subsection{The difference between teachers already giving up the selection examination and those still unsettled} displaced teachers 
This passage will discuss the difference between teachers already giving up the selection examination and those still unsettled displaced teachers. As to the intention of being teachers, the four (4) (I to L) already giving up the selection examination and changing career all show that they were not aiming as being teachers at the very beginning. Instead, they were compelled to select the department of education when filling in the aspiration. And the reasons for the selection included recommendation of parents (J, K, L) and wish of studying in Taipei (I). The reason for the recommendation of parents was the stability of the job, the handsome salary, and the reputation of teacher. Another eight (8) still preparing the selection examination or already passing the examination then had the wish of being teachers when young, the reasons included the parents' being teachers (B, $\mathrm{G}, \mathrm{H})$, association experience gained in service in college, positive experience of leading the team $(\mathrm{A}, \mathrm{C})$ and the sense of accomplishment from teaching others (D, E, F). Therefore, the four (4) already giving up the teaching job were somewhat hesitated before entering education department in college or they stayed just for the payment and stability, but they were not determined in the heart concerning teaching, when the admission rate is low, they would leave.

The fourth-year students of Education School were not more likely to stay than those of 2nd-year for the three (3) of the leaving four (4) were all from fourth-year students of Education School. The reason for one still preparing the selection examination is apparently from their inner enthusiasm towards education, the sense of accomplishment brought by education and positive experience. All the above comes from the interest of educational job itself but not payment and stability. Just like what is found concerning question number 1, this is the different result of the in-built and end-in-itself purposefulness and external materialistic objective that cause the different result of being persistent or just giving up.

After the practicing and substitute teaching, still unsettled displaced teachers (A to $\mathrm{H}$ ) were more determined to be teachers and feeling there were no big difference between learned theory and practical teaching task. But one already giving up the selection examination generally dislike the school environment, some find it too narrow (I), lack enough challenge (K), they couldn't give full play to their strong points in the school environment, it is too dark and unfair (L), though another 1 doesn't not expel the school environment (J), they don't like it much, usually finding the big difference between the theory learned in class and practical teaching task, and they think it not practical.

After really contacting teaching, the biggest difference between the four (4) already giving up the teaching job and the other 8 is their attitude towards theory and practical teaching task. They saw the big difference between the theory and practical teaching task. They denied their educational course studied in the past in some degree. They are not fully considering their believed theory helpful. This mindset deteriorates the negative attitude towards educational work. On the contrary, the eight (8) persistent in teaching job believed the theory was helpful to practical teaching task. They first confirm their professional capacity. Thus, when there were difficulties, they wouldn't blame the insufficiency of educational theory, or deny educational system. Instead, they would find the crux of the problem.

As to the low admission rate of teacher selection examination, it has no influence on the teaching belief of one still preparing the selection examination and one already passing the examination (A to $\mathrm{H}$ ); to one once changing career but returning to prepare teacher selection examination, experience of changing career strengthened their belief of being teachers. But the frequent failure of the selection examination will influence whether the economic capacity of the displaced teacher can continue. All the examination-sitting time is set within five years after acquiring teacher's qualification. If failed in five successive years, they will give up. And all the reasons they given concerning the giving up are economic factor (the low payment of substitute teachers, difficulty in becoming a long-term supporting career). Even so, they will find job relevant to teaching, such as class trusted by busy parents about the learning of their children or reinforcement classes, only giving up entering public school as teachers.

As to the four (4) already giving up the teacher selection examination and changing career (I to L), they 
A study on the educational beliefs of displaced teachers in Taiwan

chose another career directly after one selection examination. And the three (3) of them had direct relations to the low admission rate of selection examination (I, J, K), the 1 of them (L) was purely disliking the school environment, after changing the track, all the four (4) engaged in career irrelevant to educational work, namely house agent, custom officer, administer civil servant, and company accountant.

To sum up, parents, school, and teaching attitude are not the important factors deciding displaced teachers to continue sitting the teacher selection examination. And it is also difficult to make judgment based on the above on whether they will persist. The only difference lies in that one continuing to prepare selection examination after the on-site teaching all considered that there is big difference between theory and practical teaching task. They generally agreed with the education principle and theory learned in college. And they had positive attitude towards difficulties confronted. And the four (4) already giving up the teacher selection examination and changing career thought there was big difference between theory and practical teaching task, considering it unnecessary to closely follow education theory. They tended to have negative attitude towards the dark side of the school environment where they practice. However, the researcher thinks it is the attitude formerly held when choosing teaching that causes the different attitude.

Although no one can expel the external factors when choosing job (such as working payment and reputation), if one have ardent love towards teaching itself and its comfortableness, he will tend to choose teaching as a life-long career and he will persist. Otherwise, if considering mainly external factors when making the choice at the beginning without inner value clarification, then he tends to give up in face of difficulty. And this factor is the main reason for the perseverance or give-up.

\section{Conclusion}

This research takes twelve (12) displaced teachers as participants in the case study, drawing comparison between one persistent in taking the teacher selection examination and one giving up, to discuss teaching belief and factors influencing it. The research is accomplished by adopting the qualitative study paradigm and using the depth interview to collect materials, analyzed and discussed. This chapter first put forward the research conclusion, and then tries to offer several suggestions for further reference for selecting teachers and future researchers.

\subsection{Teaching belief comes from one's inner value expectation of educational work, and this expectation usually \\ takes shape from early experience and not during the process of teacher training}

Through the situation caused by the excessive opening up of Taiwan's teacher training system, a displaced teacher is willing to try again and again to be teachers, even under the low admission rate of teacher selection examination. In fact, the teaching belief of one giving up the teacher selection examination or not has already taken shape before entering the teacher training organization. Most of the belief comes from the values brought by the family, exploration of self interest, and social expectation. Many research (Bush, 1982; Calderhead \& Miller, 1986; Nespor, 1985; Pajares, 1992; Raymond, 1993) points out that teaching belief are indeed influenced by early experience. And main source of such beliefs is not gained from teacher training organization; instead, most was influenced by their parents and teachers during school-days. Just as what Calderhead \& Miller (1986) pointed out, teachers would judge which was positive and which was negative from the teaching attitude of former teachers and they would learn from the positive ones.

From the perspective of psychology, early experience is the basis of latter one, having greatly influence by the values, attitude, and behavior of the individuals. The relations to parents in early experience of childhood can greatly influence the development of individual characteristic. And they are viewed as significant others in the heart of parents. In the research, values of parents indeed have great influence on the teaching belief of the individuals, however, it doesn't represent that they will adhere to that educational belief. The main reason is that values influence of the parents is a kind of social expectation. If the wish of becoming a teacher is simply 
coming from the admiration of parents or the identification with the values of parents (wherein teachers have high social status in the community), then his/her values towards education cannot be called "in-built", and career changing will be very probable in face of difficulties.

From the above discussion, it can be judged that, the teaching belief of student teachers takes shape in early period. To trainers of teachers' qualification, it is indeed a challenge. Good as the teaching knowledge of the trainer of teachers' qualification, if it is not compatible with the teaching belief gained through introspection of early experience of student teachers, then it won't be inculcated into the hearts of student teachers, and there is no desired teaching result. From another perspective, if the teaching belief gained through introspection of early experience of student teachers is not completely correct, and then trainers of teachers' qualification have no choice but feel anxious. How to break the deadlock and assist the student teachers to correct the formerly formed teaching belief not conforming to the essence of teaching is apparently becoming one important subject in teachers' qualification training.

\subsection{In-built and external purposefulness distinguishes the perseverance or abandonment of teaching}

The so-called purposefulness refers to that of the expectation of teaching is education for education's sake, that is to say, teaching activity is end-in-itself, in-built, non-tool, nor non-materialistic, and it is not activity with motivation and objective beyond education. This in-built purposeful choice was made according to early experience, and was gradually determined in the process of teachers' qualification training, then teachers' career commitment formed. It was found in the interview that, concerning in-built purposefulness, the reason for the representative eight (8) displaced teachers who choose their teaching job was the sense of accomplishment, the liking of getting along with children, the feeling of enjoying teaching, experience of association or teaching. All of these were the feeling from personal experience. Thus, it is defined as in-built purposefulness. Though no one mention the catalysis brought by teacher training centre and practical teaching task, the value identification of teaching objective through these feelings and the wish of devoting much more to teaching career can be found. When entering practical school domain, one identifying with the teaching theory and its practical function as well as one positively looking at the school environment will move from feeling identification to teachers' career commitment, namely the teachers' acceptation of teaching objective and values and belief. They consider teaching valuable and hopeful and worth striving, and they take pride in being teachers. This process of internalization of teaching values can be found before entering teacher training organization. Career confidence can be gradually established through gradually accumulating knowledge in the stage of teaching training. Then there will be impetus for overcoming difficulty and self further training in practical teaching task.

External purposefulness refers to that the expectation of teaching is not in-built, but instrumental and materialistic, and teaching is activity with motivation and objective beyond education itself, what they pursue is the external value of teaching. The choice of this external purposefulness was also formed according to early experience. According to the result of interview, most was influenced by values of family and social expectation. When it comes to external purposefulness, the reason for the representative 4 displaced teachers who choose their teaching job was the handsome salary of teaching and the stable payment. These beliefs are relevant to the values of their parents. Teaching is not job arousing most of their enthusiasm. Thus, it is defined here as external purposefulness. For lacking enthusiasm and activity, teaching can be easily substituted when there is another job with more salary and more stable payment. Of course, this external purposefulness only varies in degree. It is difficult to people choosing a job fully expelling external purposefulness. The interesting thing is that, there was no special distortion of teaching belief of these choosing teaching for external purposefulness found in the interview: for fun (A, D, E, K, L), emphasis on teaching about moral and handling affairs (C), order (F, J), class management and communication with students $(\mathrm{H})$, enlightenment on imagination and deduction capacity $(\mathrm{J})$, what students had learned in the school $(\mathrm{G})$, attention to lay solid foundation of knowledge (I), and the difference among three groups is not distinguished. However, this doesn't show that we should pay little attention to whether teachers have enthusiasm or not, when lacking the enthusiasm, the above teachers' career commitment cannot be fulfilled. Besides, the negativity of solving teaching problem and receiving further education can be 
A study on the educational beliefs of displaced teachers in Taiwan

predicted. All of these are not the ideal selection of teachers. After all, the teacher meeting the requirement and having enthusiasm and bringing students with better things can indeed make a difference.

\subsection{In the respect of influencing factors, values of parents can influence the selection of being teachers, but \\ learning experience of school-days have the greatest influence on teaching belief}

Individual factor in the influencing factors of teaching belief is closely related to the afore-mentioned external purposefulness. It is better to say that the teaching belief of displaced teachers persisting in teaching or giving up is influenced by the observed phenomenon than it is horizon that determines the observed phenomenon. Individual's observation and sharing on the phenomenon can gradually explore the integral concept and value of its teaching belief. This individual factor is closely related to the feeling of entering the teaching domain. If one chooses the teaching position because of in-built purposefulness and has good interaction with teachers, administrative staff, parents of students, and students, this stage is important period for developing teachers' career commitment for it further confirms that working domain correspond to the environment of self-realization. Besides, it is also found in the interview that if one chooses the teaching position because of external purposefulness, though many of them confronted no difficulties from teachers, parents of students or students, nor there was big frustration in teaching, they still viewed at what was being taught and education environment with the critical eye. This situation doesn't necessarily show they will choose career changing, but in face of the predicament of low admission rate, the possibility of changing career is rather high. Though critical thinking is one impetus improving teaching environment, but when teacher career commitment is not developed, people will still have doubts about the continuation of the enthusiasm towards teaching.

As to environment factor in the influencing factors of teaching belief, values of parents influences the choice of teaching, but learning experience of school-days have the greatest influence on teaching belief. Parents of the twelve (12) displaced teachers accepting the interview all consent to or encourage them to choose teaching as the career. But what really influences the teaching enthusiasm is the purposefulness of being teachers. Their teachers when they were students are what really influence their teaching belief. Teaching mode and attitude of their primary school teachers can become the object imitated by the later teachers. And their emphasized class teaching idea won't escape the past learning experience. As to experience of practicing, though the current system situation makes it rather loose in Taiwan, teaching belief of those accepting the interview is seldom influenced. Instead, experience of teaching as the substitute teacher is more practical in teaching. But when meeting bad practicing guiding teacher, there will negative influence on the teaching belief of practicing teacher.

Finally, it is factor of holding the position. This research focus on two different teaching beliefs: why displaced teachers persist or give up. It is different from the traditional factor of holding the position in emphasizing teachers and school environment. The main reason is that factor of holding the position is influenced by school culture, and length of teaching service after the teacher entering school, and many others. Displaced teacher can only teach as the substitute teacher, and the school has no special demand of them, they have little chance of interacting deeply with school culture and colleagues, thus, in this part, no influence is exerted to the teaching belief of displaced teachers. 


\section{References:}

Abelson, R. (1979). Differences between belief system and knowledge system. Cognitive Science, 3, 335-366. doi:10.1207/s15516709cog0304_4<http://dx.doi.org/10.1207/s15516709cog0304_4>

Bauch, P. (1982). Prediction elementary classroom teaching practices from teachers' educational beliefs. Paper presented at the annual meeting of the American Educational Research Association, New York. (ERIC Document Reproduction Service NO. ED226437)

Bauch, P. (1984). The impact of teachers' instructional belief on their teaching: Implication for research and practice. Paper presented at the annual meeting of the American Educational Research Association, New Orleans. (ERIC Document Reproduction Service NO. ED 252954)

Bennet, N. (1976). Teaching styles and pupil progress. London: Open Books.

Bishop, J. M. (1972). Organizational work context, informal organizations, and the development of occupational ideologies among elementary teachers: A comparative study of 24 public schools. Unpublished doctoral dissertation, University of California, Los Angeles.

Brousseau, B. A., Book, C., \& Byers, J. L. (1988). Teacher beliefs and the cultures of teaching. Journal of Teacher Education, 39(6), 33-39. doi:10.1177/002248718803900607 <http://dx.doi.org/10.1177/002248718803900607>

Bush, W. S. (1982). Pre-service secondary mathematics teacher's knowledge about teaching mathematics and decision-making processes during teacher training. Unpublished doctoral dissertation, University of Georgia.

Cabello, B., \& Burstein, N. (1995). Examining teachers' beliefs about teaching in culturally diverse classrooms. Journal of Teacher Education, 46(4), 285-294. doi:10.1177/0022487195046004007 <http://dx.doi.org/10.1177/0022487195046004007>

Calderhead, J. (1981). A psychological approach to research on teachers' classroom decision-making. British Educational Research Journal, 7(1), 51-57. doi:10.1080/0141192810070105 $<$ http://dx.doi.org/10.1080/0141192810070105>

Calderhead, J. (1983). Research into teachers, and student teachers, cognitions: Exploring the nature of classroom practice. (Eric Document Reproduction Service NO. 229366)

Calderhead, J. \& Miller, E. (1983). The integration of subject matter knowledge in student teachers' classroom practice. Research Monograph, School of Education, University of Lancaster.

Chen, X. M. (2004). Research of social sciences. [In Chinese] Taipei: Wunan Book, Company Limited.

Clark, C. M. (1988). Asking the right questions about teacher preparation: Contributions of research on teaching thinking. Educational Researcher, 17(2), 5-12.

Clark, C. M., \& Peterson, P. L. (1986). Teachers' thought processes. In M. C. Wittrock (Ed.) Handbook of research on teaching (3rd ed.). New York: Macmillan.

Gao, Q. H. (1992). A study of teachers' beliefs and the significance of in educational innovation of schools theory. [In Chinese] Journal of Education Research Institute of National Taiwan Normal University, 30, 85-113.

Gao, Q. H. (1993). On the significance, structure and properties of belief. [In Chinese] Modern Education, 7(30), 74-89.

Garmon, M. A. (2009). Changing pre-service teachers' attitudes/beliefs about diversity: What are the critical factors? Journal of Teacher Education, 55(3), 201-213. doi:10.1177/0022487104263080 $<$ http://dx.doi.org/10.1177/0022487104263080>

Guba, E. G., \& Lincoln, Y. S. (1994). Competing paradigms in qualitative research. In N. K. Denzin \& Y. S. Lincoln (Eds.), Handbook of qualitative research (pp. 105-117). Thousand Oaks, CA: Sage

Guo, Y. S. (2001). Research methods of psychology and education. [In Chinese] Jinghua Bookstore.

Harvey, O. J. (1986). Belief systems and attitudes toward death penalty and other punishments. Journal of Psychology, 54, 143-159.

Huang, R. Q. (1991). Qualitative methods of education research. [In Chinese] Taipei: Psychology Press. Huang, M. (1994). A study of education beliefs of teachers in public primary schools: with two primary school 
A study on the educational beliefs of displaced teachers in Taiwan

teachers as the cases. [In Chinese] Unpublished masteral thesis, Institute of Primary Education, National Taiwan Normal University.

Kennedy, M. M. (2006). Knowledge and vision in teaching. Journal of Teacher Education, 57(3), 205-211. doi: 10.1177/0022487105285639 <http://dx.doi.org/10.1177/0022487105285639>

Lan, X. Y. (1995). A study of the teaching beliefs of mandarin teachers in public secondary schools and the factors forming the teaching beliefs in Taiwan. [In Chinese] Unpublished masteral thesis, Institute of Education, National Taiwan Normal University.

Lasley, T. J. (1980). Preservice teacher beliefs about teaching. Journal of Teacher Education, 31(4), 38-41. doi:10.1177/002248718003100410 <http://dx.doi.org/10.1177/002248718003100410>

LeCompte, M. D., Preissle, J., \& Teach, R. (1993). Ethnography and qualitative design in education research (2nd ed.). New York: Academic Press.

Levin, B. (2009). Investigating the content and sources of teacher candidates' personal practical theories (PPTS). Journal of Teacher Education, 59(1), 55-68. doi:10.1177/0022487107310749 <http://dx.doi.org/10.1177/0022487107310749>

Lin, C. X. (1987). A study of autonomy of junior high school teachers. [In Chinese] Unpublished masteral thesis, Graduate Institute of Elementary and Secondary Education, National Taipei University of Education.

Ling, Q. C. (1990). A relevance study of the teaching beliefs of the teachers of public primary schools in Taiwan. [In Chinese] Unpublished masteral thesis, Institute of Education, National Chengchi University.

Mayer, R. H. (1985). Recent research on teacher beliefs and its use in the improvement of instruction. Paper presented at the annual meeting of the American Educational Research Association, Chicago, IL. (ERIC Document Reproduction Service No. 259457)

Nespor, J. (1985). The role of beliefs in practice of teaching: Final report of the teacher beliefs study. (ERIC Document Reproduction Service NO. ED279446)

O'Loughlin, M. (1989). The influence of teachers' beliefs about knowledge, teaching and learning on their pedagogy: A constructivist re-conceptualization and research agenda for teacher education. (ERIC Document Reproduction Service NO. ED339679)

Ou, Y. S. (1995). Qualitative research. [In Chinese] Taipei: National Taiwan Normal University Press.

Pajares, M. F. (1992). Teachers' belief and educational research: Cleaning up a messy construct. Review of Educational Research, 62(3), 307-332.

Pan, Y. F. (1996). A study of the relationship between scientific beliefs and teaching beliefs, teaching behaviors of teachers in public secondary schools. [In Chinese] Unpublished masteral thesis, Institute of Education, National Chengchi University.

Pearson, J. (1982). On the nature of congruency between teacher cognitive reality and their observed behavioral reality. Unpublished doctoral dissertation, University of Houston.

Pearson, A. T. (1989). The teacher: Theory and practice in teacher education. New York: Routledge.

Raymond, A. M. (1993). Unraveling the relationships between beginning elementary teachers' mathematics beliefs and teaching practices. (ERIC Document Reproduction Service NO. ED390694)

Sigel, I. E. (1985). A conceptual analysis of beliefs. In I. E. Sigel (Ed.) Parental belief systems: The psychological consequences for children (pp. 345-371). Hillsdale, NJ: Erlbaum.

Simpson, J. A., \& Weiner, E. S. C. (1989). The oxford English dictionary. New York: Oxford University Press.

Stenhouse, L. (1985). Research as a basis for teaching. London, UK: Heinemann.

Tabachinick, B. R., \& Zeichiner, K. M. (1985). The development of teacher perspectives: Final report. Location: Research Center. (ERIC Document Reproduction Service No. ED266099)

Tang, R. Y. (1993). A study of the relationship between teaching beliefs and teaching behaviors of teachers in public primary schools. [In Chinese] Unpublished masteral thesis, Institute of Education, National Taiwan Normal University.

Tatto, M. T. (1998). The influence of teacher education on teachers' beliefs about purposes of education, roles, and practice. Journal of Teacher Education, 49(1), 66-77. doi:10.1177/0022487198049001008 <http://dx.doi.org/10.1177/0022487198049001008>

Wang, G. Z. (2000). An analysis of teaching beliefs of teachers and teaching practice. [In Chinese] Education 
Research Information, 8(2), 84-94.

Wu, Q. S. (1998). A study of educational innovations. [In Chinese] Taipei, Taiwan: National Taiwan Normal University Press.

Wu, Z. Y., \& Li, F. R. (translators) (1995). In M. Q. Patton. Qualitative evaluation and research methods. [In Chinese] Hsintien: Laurel (Originally published in 1990).

Yan, M. Z. (1996). A study of the relationship between the teaching beliefs of public primary schools, teacher effectiveness and teaching behavior. [In Chinese] Unpublished masteral thesis, Institute of Education, National Pingtung Teachers College.

Yu, H. Y. (1998). Social research ethics. In Xiangluan Yuang (Ed.), Danger and secret: Research ethics. [In Chinese] Taipei: San-min Bookstore.

Zhou, S. H. (1999). A study of the beliefs of a teacher majored in mandarin in a public primary school. [In Chinese] Unpublished masteral thesis, Graduate Institute of Elementary and Secondary Education, National Taipei University of Education.

Zhuang, S. Q. (1998). A study of mathematic beliefs of teachers in public primary schools. [In Chinese] Unpublished masteral thesis, Institute of Education, National Chiayi Teachers College. 